Board of Governors of the Federal Reserve System

International Finance Discussion Papers

Number 700

March 2001

\title{
A RETROSPECTIVE ON J. DENIS SARGAN AND HIS CONTRIBUTIONS TO ECONOMETRICS
}

Neil R. Ericsson, Esfandiar Maasoumi, and Grayham E. Mizon

NOTE: International Finance Discussion Papers are preliminary materials circulated to stimulate discussion and critical comment. References to International Finance Discussion Papers (other than an acknowledgment that the writer has had access to unpublished material) should be cleared with the author or authors. Recent IFDPs are available at www.federalreserve.gov/pubs/ifdp/ on the Web. 


\title{
A RETROSPECTIVE ON J. DENIS SARGAN AND HIS CONTRIBUTIONS TO ECONOMETRICS
}

\author{
Neil R. Ericsson, Esfandiar Maasoumi, and Grayham E. Mizon*
}

Abstract: This retrospective provides a biographical history of Denis Sargan's career and reviews his contributions to econometrics, emphasizing the breadth of his work in both theoretical and applied econometrics. We include a complete bibliography for Denis and a list of $\mathrm{PhD}$ theses that he supervised - students were a substantive facet of his professional life. Finally, two of Denis's previously unpublished manuscripts on model building now appear in print.

Keywords: dynamic specification, econometrics, error correction model, finite sample distributions, identification, instrumental variables, model building, numerical computation, prices, production function, specification searches, wages.

JEL classifications: $\mathrm{C} 1, \mathrm{C} 5$.

\footnotetext{
*Forthcoming in Econometric Reviews (2001) Vol. 20, No. 2, under the title "A Retrospective on J. Denis Sargan". The first author is a staff economist in the Division of International Finance, Board of Governors of the Federal Reserve System, Washington, D.C. 20551 USA, the second author is the Robert H. and Nancy Dedman Professor of Economics in the Department of Economics, Southern Methodist University, Dallas, Texas 75275-0496 USA, and the third author is the Leverhulme Professor of Econometrics in the Department of Economics, University of Southampton, Southampton SO17 1BJ England. The authors may be reached on the Internet at ericsson@frb.gov, maasoumi@post.cis.smu.edu, and grayham.mizon@soton.ac.uk respectively. The views in this paper are solely the responsibility of the authors and should not be interpreted as reflecting the views of the Board of Governors of the Federal Reserve System or of any other person associated with the Federal Reserve System. The obituaries in Mizon (1996) and Desai, Hendry, and Mizon (1997), the research underlying Hendry and Wallis (1984) and Maasoumi (1988a, 1988b), and the Econometric Theory interview by Phillips (1985) have provided valuable material for writing this retrospective. Financial support from the UK Economic and Social Research Council under grant L138251009 is gratefully acknowledged. We are indebted to Mary Sargan for permission to publish Denis's manuscripts "Model Building and Data Mining" and "The Choice Between Sets of Regressors"; and to Gregg Forte, Dale Henderson, David Hendry, Jaime Marquez, Mary Sargan, Hayden Smith, and Cathy Tunis for valuable comments and suggestions. BIвT $\mathrm{E}$ X bibliographic files for Denis's papers and for his $\mathrm{PhD}$ students' theses are available from the first author and at www.federalreserve.gov/pubs/ifdp/2001/700/default.htm on the WorldWide Web. This paper is being simultaneously circulated as Discussion Paper in Economics and Econometrics No. 0108 by the Department of Economics at the University of Southamption and as International Finance Discussion Paper No. 700 by the Board of Governors of the Federal Reserve System, available on the WorldWide Web at www.soton.ac.uk/ econweb/dp/dp01.html and www.federalreserve.gov/pubs/ifdp/2001/700/default.htm respectively.
} 


\section{Introduction}

Denis Sargan (1924-1996) was the leading British econometrician of his generation, playing a central role in establishing the technical basis for modern time series econometrics. Denis had a distinguished career spanning more than forty years as a teacher, researcher, and practitioner, particularly while he was Professor of Econometrics at the London School of Economics (LSE), where he transformed both the econometric analysis of macroeconomic time series and the teaching of econometrics.

This retrospective summarizes those contributions, providing a perspective gained in part as students and then as colleagues of Denis's during his tenure at the LSE. Section 2 provides a biographical history of Denis's career. Subsequent sections briefly review his econometric contributions, which were primarily in three areas:

1. statistical inference (Section 3), including instrumental variables estimation and testing, finite sample distributions, and identification;

2. empirical analysis of wages and prices and of production functions (Section 4); and

3. model building (Section 5), including dynamic specification, numerical computation, and specification searches.

The body of our paper is followed by a complete chronological bibliography for Denis, and Table 1 in Section 3 categorizes each of his papers by its focus on one or more of the categories within these three topics. Denis's PhD students also represented a substantive facet of his professional activities: thesis topics sometimes built upon his own research and, if not, reflected his broad interests in econometric issues. A list of his PhD students' theses follows Denis's chronological bibliography, and Table 2 categorizes those theses according to the topics above. Two of Denis's previously unpublished manuscripts on model building now appear in print in Econometric Reviews, directly following the published version of this retrospective. Section 5.3 discusses the contributions of these manuscripts and their relationships to more recent literature.

\section{Career}

Denis was born in Doncaster, Yorkshire, on August 23, 1924, and attended Doncaster Grammar School, where his mathematical ability was recognized and developed. He then gained a State Scholarship and entrance to St. John's College, Cambridge, where he obtained a BA in Mathematics (1st Class Honors) in 1944. In fact, Denis was the "Senior Wrangler" - he received the best mathematics degree in his year. During 1943-1946, Denis was a Junior Scientific Officer attached to the RAF Coastal Command, helping with the statistical testing of new weapons. Toward the end of the war, 
he read Keynes's General Theory, which made him optimistic about what economics could accomplish, e.g., by designing policies to avoid the high levels of unemployment experienced interwar. Denis also noted Keynes's extensive use of mathematics in the General Theory, which suggested an enormous potential for successful application of mathematics and statistics in economics. Denis returned to St. John's and obtained a $\mathrm{BA}$ in economics in 1948. He then became a Lecturer in the Economics Department of the University of Leeds, a position that he held for over a decade.

While at Leeds, Denis taught courses on the collection, interpretation, and use of economic statistics. He also undertook theoretical and empirical research on economic growth and the distribution of wealth and published several papers thereon. Denis soon became interested in developing a small econometric model of the UK economy, but was hindered by inadequate computing facilities, poor data, and the lack of other researchers with whom he could discuss econometric issues. Even so, Denis began research in theoretical econometrics, deriving and publishing properties of the instrumental variable estimator for models with either white noise or autoregressive errors in Sargan (1958a, 1959a).

In 1958, Denis received a Fulbright scholarship, enabling him (with his family) to visit the University of Minnesota and the University of Chicago between 1958 and 1960. Stimulating discussions with John Chipman, Franklin Fisher, and Zvi Griliches solidified his interest in econometrics. On returning to the United Kingdom, Denis rapidly established a reputation for rigorous and original research in the econometric analysis of time series data. Just five years after publishing his first paper in econometrics, Denis was elected as a Fellow of the Econometric Society in 1963 and, in the same year, moved to the LSE as a Reader in Statistics. Two years later Denis was appointed Professor of Econometrics in the Economics Department at the LSE. In 1982, he was appointed Tooke Professor of Economic Science and Statistics at the LSE, a position that he held until his retirement in 1984, when the University of London conferred upon him the title Emeritus Professor of Economic Science and Statistics.

Denis's appointment at the LSE was an important part of a major expansion in the School's graduate training of economists. In 1965, the LSE introduced an MSc (Master of Science) course in Economics and a more specialized MSc course in Mathematical Economics and Econometrics; and the number of PhD students working in theoretical economics and econometrics increased markedly over the next few years. Denis's teaching of the undergraduate and graduate econometric theory courses at the LSE was legendary. The content - often from the frontiers of research — itself provided students with a challenge. That challenge was increased by Denis's habit of changing notation, sometimes several times in one proof, while filling blackboard after blackboard with his derivations. Equally memorably, Denis would often lecture without reference to his notes, remembering from week to week what topic he was discussing. 
Notably, much of Denis's and his students' research was embedded in applied econometric studies. This has not been widely appreciated in the economics profession. For example, while at Leeds, Denis discovered an apparently stable relationship between inflation and unemployment. However, he could not believe that a small increase in unemployment would substantially reduce inflation. Further work on this topic generated his "Colston paper" (as he called it) — Sargan (1964c) — containing some of his most important econometric contributions. Even much later in life and with many additional accomplishments to his name, Denis regarded his Colston paper as a, if not the, pinnacle of his academic career.

The heart of Sargan (1964c) is a dynamic empirical wage-price markup model for the United Kingdom, which Denis formulated as an "error correction model" or ECM. This class of model now pervades empirical macroeconomic modeling, and it provides the dynamic representation of cointegration. With this model, Denis demonstrated the importance of real-wage resistance in wage bargains through a "catch-up" mechanism that recoups losses incurred from unanticipated inflation. Sargan (1964c) also developed a new treatment of serially dependent errors in time series models, showed how to test hypotheses validly after estimating dynamic models, and established convergence results for nonlinear iterative procedures. Here and elsewhere, Denis stressed the importance of rigorous diagnostic testing. In his Colston paper alone, he developed and implemented new procedures for testing common factors, autocorrelation in dynamic models, functional form, instrument validity, and dynamic specification. At a more general level, by carefully matching econometric theory to a substantive economic problem, Denis created an exemplar for the econometric modeling of time series data in economics. Sargan (1964c) still merits reading, both for its seminal contributions and as a paradigm in empirical modeling.

While at the LSE, Denis supervised most PhD students in econometrics. Table 2 below documents the broad range of his students' thesis topics, which included the formulation, estimation, and testing of alternative dynamic model specifications; hypothesis testing in systems of equations; the treatment of missing observations in multivariate time series models; semi-parametric estimation of systems using FIML (full information maximum likelihood) and spectral estimates of the error covariance matrix; nonlinear estimation methods; inference with continuous time models; and finite sample distribution theory and higher-order asymptotic expansions to provide small sample approximations to distribution functions. Many of these topics were tied closely to applied econometric studies, including models of wages and prices, aggregate durable and non-durable consumer demand, aggregate production, investment and inventory behavior, and import and export determination.

Denis created a research workshop for presentation and discussion of research output, which provided a model followed by many of his students in their own teaching careers. In this workshop and in meetings with students and colleagues, Denis's agility of mind and generosity of spirit were often evident. As was typical of Denis, he 
was quite happy just to encourage and stimulate students' and colleagues' research through his insights, only occasionally publishing results from those interactions. Denis likewise had an abundant supply of unpublished papers waiting for his revision, although they often appeared to be innovative and complete already. Six such papers appeared in Maasoumi (1988); two more appear in an issue of Econometric Reviews.

Denis encouraged social interaction with students by inviting some of them to his home in the London suburb of Rickmansworth. On these occasions, we realized the importance to Denis of his relationship with Mary (whom he married in 1953 while at Leeds) and their children, and also became aware of his interest in gardening and music. It was a pleasure to see Mary and Denis at the many econometrics conferences to which he was invited to present papers, after which they would take the opportunity to visit art galleries, museums, and archeological sites.

The creation of the SSRC (Social Science Research Council) Econometrics Study Group was an important development for econometrics in the United Kingdom. This workshop met five or six times a year on Friday afternoons at the LSE to hear and discuss a wide range of econometric papers. Denis regularly attended these meetings and was an important contributor to them. Quite fittingly, the Study Group held a special conference at St. Peter's College, Oxford in 1984 in Denis's honor, with Franklin Fisher giving a warm and amusing speech recalling his interactions with Denis and evaluating Denis's contributions to econometrics.

Denis did not seek honors or awards but was pleased when they came. He was elected as President of the Econometric Society in 1980, made a Fellow of the British Academy in 1981, made an honorary foreign member of the American Academy of Arts and Sciences in 1987, and given an honorary doctorate by the University of Carlos III, Madrid in 1993. Denis died at his home in Theydon Bois, Essex, England, on April 13, 1996.

\section{Contributions to Statistical Inference}

Denis's econometric contributions were primarily in statistical inference, empirical analysis, and model building — as discussed in this and the following two sections. To help guide and clarify the nature of Denis's contributions, Table 1 categorizes each of his papers by its focus on one or more categories within these three topics. Maasoumi (1988b, Chapter 1) summarizes Denis's contributions to economic theory.

The current section examines Denis's contributions to statistical inference, which centered on instrumental variables estimation and testing (Section 3.1), finite sample distributions (Section 3.2), and identification (Section 3.3). As Table 1 highlights, and as is brought out below, instrumental variables procedures and small sample properties - jointly and in conjunction with dynamic specification (Section 5.1) formed the nexus for much of Denis's research. 
Table 1. A Categorization of Articles Published by J. Denis Sargan.

\begin{tabular}{|c|c|c|c|c|c|c|c|c|c|}
\hline \multirow[b]{2}{*}{ Article } & \multicolumn{3}{|c|}{ Statistical Inference } & \multicolumn{3}{|c|}{ Model Building } & \multicolumn{2}{|c|}{ Empirics } & \multirow{2}{*}{$\begin{array}{l}\text { Ec. } \\
\text { Th. }\end{array}$} \\
\hline & $\overline{I V}$ & $\begin{array}{c}\text { Finite } \\
\text { samples }\end{array}$ & $\overline{\text { Ident. }}$ & $\begin{array}{l}\text { Dyn. } \\
\text { spec. }\end{array}$ & $\begin{array}{l}\text { Num. } \\
\text { comp. }\end{array}$ & $\begin{array}{c}\text { Spec. } \\
\text { search }\end{array}$ & $\begin{array}{l}\text { Wages, } \\
\text { prices }\end{array}$ & $\begin{array}{c}\text { Prod. } \\
\text { fn. }\end{array}$ & \\
\hline $\begin{array}{l}\text { Sargan }(1951) \\
\text { Sargan }(1952) \\
\text { Sargan }(1953 a) \\
\text { Sargan }(1953 b) \\
\text { Sargan }(1955)\end{array}$ & & $\bullet$ & & • & & & & $\bullet$ & : \\
\hline $\begin{array}{l}\text { Sargan }(1956) \\
\text { Sargan }(1957 \mathrm{a}) \\
\text { Sargan }(1957 \mathrm{~b}) \\
\text { Sargan }(1958 \mathrm{a}) \\
\text { Sargan }(1958 \mathrm{~b})\end{array}$ & $\bullet$ & & $\bullet$ & & & $\bullet$ & & $\bullet$ & : \\
\hline $\begin{array}{l}\text { Sargan }(1958 c) \\
\text { Sargan }(1959 a) \\
\text { Sargan }(1959 b) \\
\text { Sargan }(1961 a) \\
\text { Sargan }(1961 b)\end{array}$ & $\bullet$ & & • & • & • & $\bullet$ & & • & $\bullet$ \\
\hline $\begin{array}{l}\text { Sargan }(1964 \mathrm{a}) \\
\text { Sargan }(1964 \mathrm{~b}) \\
\text { Sargan }(1964 \mathrm{c}) \\
\text { Layard et al. } 1971) \\
\text { Sargan (1971a) }\end{array}$ & $\begin{array}{l}\bullet \\
\bullet \\
\bullet\end{array}$ & $\begin{array}{l}\bullet \\
\bullet\end{array}$ & $\bullet$ & • & $\ddot{\bullet}$ & $\bullet$ & $\bullet$ & • & $\bullet$ \\
\hline $\begin{array}{l}\text { Sargan }(1971 b) \\
\text { Sargan }(1971 c) \\
\text { Sargan and Mikhail (1971) } \\
\text { Sargan (1974a) } \\
\text { Sargan (1974b) }\end{array}$ & $\dot{\bullet}$ & • & & • & $\bullet$ & $\bullet$ & • & $\bullet$ & \\
\hline $\begin{array}{l}\text { Sargan and Drettakis (1974) } \\
\text { Sargan }(1975 \mathrm{a}) \\
\text { Sargan }(1975 \mathrm{~b}) \\
\text { Sargan }(1976 \mathrm{a}) \\
\text { Sargan }(1976 \mathrm{~b})\end{array}$ & $\begin{array}{l}\bullet \\
\bullet \\
\bullet\end{array}$ & : & & $\bullet$ & $\bullet$ & $\bullet$ & & & \\
\hline $\begin{array}{l}\text { Espasa and Sargan (1977) } \\
\text { Sargan }(1978) \\
\text { Sargan }(1980 a) \\
\text { Sargan }(1980 b) \\
\text { Sargan }(1980 c)\end{array}$ & $\begin{array}{l}\bullet \\
\bullet \\
\bullet\end{array}$ & $\bullet$ & & • & $\bullet$ & $\bullet$ & $\begin{array}{l}\bullet \\
\bullet \\
\bullet\end{array}$ & & \\
\hline $\begin{array}{l}\text { Sargan }(1980 \mathrm{~d}) \\
\text { Sargan }(1981) \\
\text { Sargan and Tse (1981) } \\
\text { Sargan (1982) } \\
\text { Bhargava and Sargan (1983) }\end{array}$ & $\bullet$ & $\begin{array}{l}\bullet \\
\bullet \\
\bullet\end{array}$ & • & : & $\bullet$ & $\bullet$ & • & & \\
\hline $\begin{array}{l}\text { Sargan (1983a) } \\
\text { Sargan (1983b) } \\
\text { Sargan and Bhargava (1983a) } \\
\text { Sargan and Bhargava (1983b) } \\
\text { Sargan and Mehta (1983) }\end{array}$ & $\bullet$ & $\bullet$ & • & : & • & $\bullet$ & • & & \\
\hline $\begin{array}{l}\text { Hendry et al. (1984) } \\
\text { Sargan and Satchell (1986) } \\
\text { Maasoumi (1988) } \\
\text { Sargan (1988a) } \\
\text { Sargan (1988b) }\end{array}$ & $\bullet$ & : & $\bullet$ & 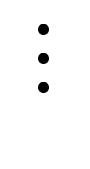 & $\bullet$ & • & • & $\bullet$ & $\bullet$ \\
\hline $\begin{array}{l}\text { Sargan }(1988 \mathrm{c}) \\
\text { Sargan }(1988 \mathrm{~d}) \\
\text { Sargan }(1988 \mathrm{e}) \\
\text { Sargan and Tse (1988a) } \\
\text { Sargan and Tse (1988b) }\end{array}$ & $\dot{\bullet}$ & $\bullet$ & • & : & $\stackrel{\bullet}{\bullet}$ & $\bullet$ & & & \\
\hline $\begin{array}{l}\text { Arellano and Sargan (1990) } \\
\text { Sargan (1993a) } \\
\text { Sargan (1993b) } \\
\text { Sargan (2001a) } \\
\text { Sargan (2001b) }\end{array}$ & $\bullet$ & : & & • & : & • & & & \\
\hline
\end{tabular}




\subsection{Instrumental Variables}

Sargan (1958a, 1959a) analyzed the instrumental variables (IV) estimator in a much more general framework than previously considered in the literature. Earlier influential contributions by Reiers $\varnothing 1$, Geary, and Durbin were restricted to relatively simple models or choices of instruments. Denis's framework allowed for arbitrary instruments, including lagged endogenous variables; and the model could be nonlinear, with a special focus on linear models with autoregressive errors. Each of Denis's two papers specified the class of model being estimated and the associated econometric "problem", derived the estimator's asymptotic distribution, showed how to test hypotheses using the estimator, compared the estimator's properties with other estimators such as OLS and LIML (limited information maximum likelihood), and examined the consequences of violations of underlying assumptions (e.g., resulting in under-identification). The relation of IV to LIML was later extended to FIML by Hausman (1975) and Hendry (1976), following Sargan (1964b).

While of substantive value in their own right, Sargan (1958a) and Sargan (1959a) also set the stage for numerous additional developments. Treating models with autoregressive errors as a specific form of nonlinearity was central to Denis's later research on dynamic specification, both in deriving tests of common factors and in formulating a typology for dynamic models; see Sargan (1980d) and Hendry, Pagan, and Sargan (1984). Derivation of the IV estimator's asymptotic properties led directly to establishing the asymptotic equivalence of three-stage least squares and FIML for standard simultaneous equations models; see Sargan (1964b). Sargan (1958a, 1959a) derived a mis-specification test statistic, equivalent to a statistic for testing over-identification, which Sargan (1980c, 1988e) then examined in much greater detail. Sargan (1958a, 1964a, 1971a) reported preliminary finite sample results for the IV estimator, paving the way for his more comprehensive studies in Sargan (1974b, 1975b, 1976a) using Nagar, Gram-Charlier, and Edgeworth approximations. Denis's formulation of IV was also the conceptual precursor to estimation and testing with generalized method of moments.

IV estimation played an important part in Denis's econometrics courses, often serving to introduce asymptotic distribution theory. Sargan (1988d, Chapters 5 and 6) is still one of the clearest presentations of the IV framework available in the literature.

\subsection{Finite Sample Distributions}

Denis Sargan, Ted Anderson, and Bob Basmann were the three undisputed deans of finite sample distribution theory for their generation. Their three schools together were primarily responsible for the technical advances in this area, and many $\mathrm{PhD}$ students and younger colleagues working on finite sample distributions were associated with at least one of these three individuals. While much of Denis's work on finite 
sample distributions was highly technical, his interest in finite sample theory stemmed from his desire to develop estimators and test statistics that would work in practice. Notably, some of his papers on finite sample distributions also included empirical illustrations. Finite sample distribution theory, along with IV estimation and dynamic specification, were Denis's central and continuing interests throughout his career.

Denis started working on finite sample properties in the 1950s - in essence, at the outset, for this literature in econometrics. Sargan (1953a) — Denis's third published paper and his first using mathematical statistics - derived an approximation to the distribution of the correlogram of an autoregressive series. To show the empirical usefulness of his approximation, Denis finished with an application to Beveridge's wheat-price series, modeled as a second-order autoregression. As Section 3.1 discusses, by the late 1950s Denis already had a preliminary assessment of the IV estimator's finite sample properties. Building on that work, Sargan (1974b, 1975b, 1976a) rigorously developed Nagar, Gram-Charlier, and Edgeworth approximations for general econometric estimators and test statistics, typically focusing on IV. Denis established conditions for the existence of finite sample moments for many econometric estimators in simultaneous equations models, including in their reduced form, which is used for forecasting. The existence of finite sample moments may be of interest for several reasons, including the tail behavior of the estimators and forecasts, and the validity and potential accuracy of analytical approximations to moments and distributions. Denis showed that reduced form estimators and forecasts derived from structural form IV estimators typically had no finite sample moments, whereas those from FIML could have some moments; see Sargan (1988a). Characteristically, Denis proposed a solution that would ensure having finite sample moments, which in turn might produce tighter forecast confidence intervals. His ideas for several other solutions to this forecasting problem were embodied in Maasoumi (1977, 1978, 1986). Denis also derived distributional properties of IV and FIML structural form estimators; see Sargan (1978, 1988b).

Approximately half of his students' theses included finite sample results (see Table 2 below). In particular, William Mikhail formulated early Gram-Charlier expansions for the IV estimator, Essie Maasoumi focused on finite sample properties of forecasts from simultaneous equations models, Yuk Tse and Steve Satchell extended and refined results for Edgeworth approximations, and Alok Bhargava analyzed finite sample properties of unit root tests — see Sargan and Mikhail (1971), Maasoumi (1986), Sargan and Tse (1981, 1988a, 1988b), Sargan and Satchell (1986), and Sargan and Bhargava (1983a, 1983b). After finishing their theses, some of Denis's students also contributed to the literature on finite sample distributions. Notably, Peter Phillips developed saddlepoint, Padé, and rational polynomial approximations; and Manuel Arellano derived an Imhof approximation — see Phillips (1983) and Arellano and Sargan (1990).

Monte Carlo studies often accompanied derivations of finite sample approxima- 
tions in order to assess how well the approximations worked in practice. Denis advocated examining Monte Carlo evidence in conjunction with finite sample approximations. Sargan (1982) in particular analyzed the properties of Monte Carlo estimates of moments when those moments are infinite in finite samples, tying the Monte Carlo results to the properties of (analytical) finite sample approximations. By the mid-1970s, Denis had already developed these ideas, which were also reflected in Maasoumi's PhD thesis. Hall (1992) has noted a similar phenomenon between Edgeworth approximations of distributions and their resampling (bootstrap) estimates. Denis's insights on Monte Carlo methodology stimulated the development of control variates in econometrics as well; see Hendry and Harrison (1974), Sargan (1976a, Appendix D), and Hendry (1984).

\subsection{Identification}

Denis's early econometric papers examined IV and nonlinear estimators, so it was natural for him to consider the identification of the models' parameters as well. Sargan (1958a, 1959a, 1961b) all discussed under-identification as well as over-identification, including test statistics for under-identification. Liu (1960) had argued that simultaneous equations models were unidentified because prior (e.g., zero) restrictions were only approximations. Denis, however, did not see the lack of identification as a likely prospect empirically. In Sargan (2001b) (written initially in 1973), Denis thought that under-identification was "probably only important in rather small models since, in models of any size, there are usually sufficiently large blocks of variables excluded from each equation to make the equation identified with any specification that the economist would consider reasonable."

Denis re-examined the issue of identification in Sargan (1983a, 1983b, 1988c). Utilizing results in Fisher (1966) and Rothenberg (1971), Denis showed how a model may satisfy a necessary but not sufficient (rank) condition for local unidentifiability, with the result that typical estimators are consistent but not asymptotic normal. Sargan (1983b) focused on linear systems with vector autoregressive errors, whereas Sargan (1983a, 1988c) considered the more general case of dynamic models linear in variables but nonlinear in parameters.

Denis also considered the consequences of over-identification. Sargan (1978, 1988a) derived the link between the sample size and degree of an equation's over-identification and the number of (existent) finite sample moments for structural and reduced form

estimators. He further demonstrated the role of over-identification for the validity of Nagar-type expansions. 


\section{Contributions to Empirical Analysis}

Denis focused on two empirical applications: the determination of wages and prices (Section 4.1), and production functions (Section 4.2). Both interests started while at Leeds University, although Denis's initial interest in production was a purely economic one (see Sargan $(1951,1955,1956,1958 b)$ ), and his first empirical research on wages and prices took roughly a decade to bear fruit — as his 1964 Colston paper, Sargan (1964c). Denis also revisited each field, both directly himself and indirectly through his students.

\subsection{Wages and Prices}

Sargan (1964c) provided innovations in empirical wage-price modeling, dynamic specification, hypothesis testing with autoregressive errors, and numerical optimization. While Sargan (1964c) estimated wage and price equations by single-equation techniques, Denis thought of those equations as belonging to a system and so used IV estimation (both regular and autoregressive). That perspective strongly influenced his approach in Sargan (1980b), in which, with faster computers and improved software, Denis modeled wages and prices jointly (with earnings) as a system of dynamic simultaneous equations. Long-run properties were derived from system FIML estimates, contrasting with the (yet) still-common approach of solving for (e.g.) the NAIRU (non-accelerating inflation rate of unemployment) from single-equation OLS estimates. In addition to the econometric developments and concerns, Sargan (1964c, 1980b) brought out economic issues such as real-wage resistance, the treatment of union influence, and the roles of productivity and unemployment.

In between these two papers, one of Denis's students, Keith Vernon, wrote his thesis on wages and prices. Drawing on that thesis, Sargan (1971c) updated the models in Sargan (1964c), finding (again) that the error correction term was statistically, numerically, and economically important. Sargan (1971c, p. 52) noted that "[e]mpirically the [error correction form] arose by noting that if the lagged real wage is introduced as a variable into a standard Phillips wage equation it is statistically significant. This is enough to reject models which exclude this variable." Denis then provided two interpretations of the error correction term, one in terms of trade-union pressure and the other as being an approximation to excess labor supply. Incidentally, during the 1960s, Bill Phillips and Denis ran a quantitative economics course at the LSE in which the latest applied econometric studies were examined. Inter alia Denis and Bill discussed the relative merits of such alternative formulations of the Phillips curve - an exciting experience for the many students that attended. See Hendry and Mizon (2000). 


\subsection{Production Functions}

Denis's bibliography has a marked gap between 1964 and 1971. Reasons included chairing the economics department, teaching, and expanding the PhD program. In 1969-1970 alone, nine of Denis's PhD students completed their theses. Addition-

ally, Denis was collaborating with several other economists at the LSE on a study examining the relationship between the educational system and the performance of qualified labor. A book - Layard, Sargan, Ager, and Jones (1971) - resulted. In Part 4 of that book, Sargan (1971b) reviewed production function analysis, proposed the trans-log production function, and empirically analyzed inter-plant production in the UK electrical engineering industry. Denis presented the trans-log function as a natural extension of Kmenta's (1967) approximation to a production function with a constant elasticity of substitution, arguing that it provided a general method of allowing elasticities of substitution to vary between factors of production. The trans$\log$ production function facilitated the testing of meaningful restrictions on returns to scale and substitution possibilities, while being relatively easy to estimate.

Denis's early economic interest in production re-surfaced in Sargan (1971b), and in the theses of several students, often in combination with other of Denis's econometric interests. For example, Mizon (1972) examined dynamic specification of vintage capital production relationships, which linked productivity to investment via putty-clay technology. Such models are highly nonlinear, and their estimation benefited from robust numerical optimization methods; see Mizon (1977).

\section{Contributions to Model Building}

Denis's work on model building included dynamic specification (Section 5.1), numerical computation (Section 5.2), and specification searches (Section 5.3). These areas were often intertwined, with (e.g.) new approaches to dynamic specification requiring innovations in numerical methods, as for the estimation and selection of models with common factors, and so the testing of common factors themselves. Denis also wrote but did not publish two manuscripts on specification searches that influenced concurrent and later research on econometric methodology. An issue of Econometric Reviews now reproduces those manuscripts.

\subsection{Dynamic Specification}

Dynamic specification was the third of Denis's dominant professional interests, and his contributions were both conceptual and inferential. At a conceptual level, Denis developed the theory of common factor restrictions ("comfac"), formalized error correction models, and (with David Hendry and Adrian Pagan) constructed a typology for dynamic models. At an inferential level, Denis designed tests of comfac, of the 
order of Almon polynomials, and of lag length, all of which contributed to the generalto-specific modeling approach embedded in the model typology. Denis's contributions to dynamic specification have affected numerous economists at a practical level witness the ubiquity of error correction models and general-to-specific modeling in applied macroeconomics.

Comfac. Sargan (1959a, 1961b, 1964c) examined dynamic models with autoregressive errors, substituting out the lagged errors to obtain the corresponding nonlinear common factor restrictions. Each paper proposed criterion-based test statistics for the restrictions. Sargan (1980d) further developed this approach, designing a nested sequence of common factor restrictions to extract increasingly higher-order autoregressive errors from a general linear dynamic model. Mizon (1995b) has noted that some empirical researchers still impose untested comfac restrictions by adding an autoregressive residual to "correct" for residual autocorrelation, rather than testing whether or not the common factor is a statistically acceptable restriction on a more general dynamic model.

ECMs. While Denis's concern for dynamic stability appeared in Sargan (1958b, 1961a), he first explicitly incorporated an error correction (or equilibrium correction) term in Sargan (1964c). Previous researchers had modeled the relationship between wages and prices as one in differences, and Denis saw the ECM as a means for dealing with the economic infelicities of an equation in differences alone.

[I] was however not satisfied with [an equation relating nominal wage growth to inflation and the unemployment rate] because it is in effect non-homogeneous in money prices. Suppose that over some time interval a large change in the price level occurs with the level of unemployment normal. According to the equation estimated by Dicks-Mireaux and Dow (1959) money wages rise by a smaller percentage than prices, and real wages fall. But unions are very conscious of the effect of price rises, and it is possible that if past changes have unfavourably affected the level of real wages, they will increase their pressure so as to correct the level of real wages again. It is possible to test this possibility by introducing one extra variable into [the nominal wage growth equation] representing real wage rates. Using a Klein linearization, $w_{t-1}-p_{t-1}$ [i.e., the log of lagged real wages] was used. When this was done the corresponding coefficient had the right sign and was significant with [a] $t$-ratio greater than three. Sargan (1964c, p. 37)

Denis's economic motivation predated by over a decade the econometric motivation provided by the cointegration literature, yet both aim to capture how some series tend to move together over time.

Dynamic typology. Hendry, Pagan, and Sargan (1984) provided a detailed treatment of dynamic specification, formulating a typology of econometric models, all of 
which are nested in an autoregressive distributed lag (ADL) model. The typology applies to both single equations and systems, and includes virtually all dynamic models used in practice. Nesting within an ADL provided a convenient conceptual structure: it also laid the foundations for testing the implied restrictions.

Lag length and lag distributions. Two central issues in dynamic specification are lag length and the shape of the lag distribution. Sargan (1980a) addressed both directly, focusing on how to test the order of an Almon polynomial. Sargan (2001a), written in 1981, generalized Anderson's (1971) sequential nested testing procedures for general linear dynamic models. This formulation embodies and characterizes the general-to-specific sequential specification searches practiced by many researchers, especially among those trained at the LSE.

\subsection{Numerical Computation}

Denis was well aware of how important satisfactory numerical algorithms were to the actual implementation of econometric techniques. Sargan (1959a) and Sargan (1961b) proposed specific algorithms for computing nonlinear IV estimates and maximum likelihood estimates respectively. The combination of theory and algorithm typified his style when proposing new estimators and test statistics. Computation alone was not sufficient, though: the properties of the algorithms themselves could be at issue. Sargan (1964c, Appendix) provided the first proof of convergence of the "method of successive maximization", which included the Cochran-Orcutt procedure. Earlier discussion in Sargan (1959a, pp. 102-103) and Sargan (1961b, p. 419) cited his result, but without proof. Sargan (1964c, Appendix) must be one of the few published appendices that has been republished by itself because its own contribution to the literature merited doing so; see Sargan (1987). Denis's adeptness with numerical methods resurfaced in Sargan (1980d), where he proposed a determinental algorithm for generating a sequence of test statistics for comfac.

Denis taught methods of numerical optimization as part of the MSc in Mathematical Economics and Econometrics, discussing algorithms such as Newton-Raphson, Gauss-Newton, and conjugate directions; see Sargan (1988d, Chapter 10). The detail of his lectures on numerical optimization was unusual for an economics program at the time, and is so even now. PhD theses written under Denis often reflected his interest in numerical methods, with most of those theses having a significant component on numerical computation; see Table 2. Notable examples included Hendry (1970) on efficient algorithms for estimating dynamic models with autoregressive errors (eventually embodied in the software package PcGive); Wymer (1970) and Phillips (1974) on the estimation of continuous time models; Mizon (1972), Sylwestrowicz (1975), and Chong (1982) on nonlinear optimization; and Espasa (1975) on spectral estimation, published in Espasa and Sargan (1977). Algorithms and programs written by one student typically were readily available to concurrent and later students and col- 
leagues, helping to avoid redundant computer programming effort within the LSE's general econometric research program.

\subsection{Specification Searches}

While most of Denis's published papers are technical, innovative, demanding contributions to theoretical econometrics, their motivation typically arose from a perceived need to construct better empirical models, as highlighted by Sargan (1964c) inter alia. Denis was well aware of "pre-test" problems in sequential modeling procedures and, as in Sargan (1980d, p. 882), he occasionally hinted at possible solutions. In fact, Denis did write specifically on such issues in two manuscripts - "Model Building and Data Mining" (in 1973) and "The Choice Between Sets of Regressors" (in 1981) — but he did not publish either. These manuscripts now appear in print as Sargan (2001b) and Sargan (2001a), directly following the published version of the current paper. Results from both manuscripts became part of the "folklore" in the LSE approach to modeling, and we are delighted to make these papers more generally available to the econometrics profession.

The paper "Model Building and Data Mining" (now Sargan (2001b)) defined the phenomenon of data mining in econometrics and discussed different types of data mining and the outcomes that they produce. Denis examined both classical and Bayesian approaches, and illustrated the issues involved with variable addition and exclusion in a standard linear regression model, the choice of lag structure in a dynamic single equation, and specification in a simultaneous equations model. Several principles central to the LSE methodology arose naturally in Sargan (2001b), including general-to-specific modeling, the importance of having a well-specified general model, parsimony, and model reduction. Denis's comments on Bayesian methods are of particular interest. While studying in Cambridge, Denis attended lectures by Harold Jeffreys on Bayesian probability; and two of Denis's classmates were the (now) well-known statisticians David Lindley and V.S. Huzurbazar. The final paragraph of Sargan (2001b) speculates on the optimum size of models, quite possibly seeding Sargan (1975a), which analyzed the asymptotics of sequences of increasingly complex models.

The paper "The Choice Between Sets of Regressors" (now Sargan (2001a)) examined the choice of critical values for testing both non-sequential and nested sequential sets of constraints in the standard linear regression model. Denis showed that modest increases in (e.g.) $t$-ratio critical values relative to their one-off values may be sufficient in some cases to maintain proper size. A Bayesian decision-theoretic approach, highlighted by the Schwarz (1978) criterion, provided a framework for deriving consistency and asymptotic local power properties of both the $t$-ratio and Bayesian forms of model search algorithms. Notably, Denis had published on testing both comfac and lag polynomials in Sargan (1980d) and Sargan (1980a) just prior to writing this 
manuscript, so sequential testing and the corresponding issues of data mining were apt to be on his mind.

Even as unpublished manuscripts, the influence of Sargan (2001a, 2001b) is evident in others' work, including Maasoumi (1978) on quasi-Bayesian and James-Stein approaches, Maasoumi (1980) on generalized ridge regression, Mizon (1995a) on model specification searches, and Campos and Ericsson (1999) and Hendry (2000, Chapter 20) on data mining. With Sargan (2001a) and Sargan (2001b) now in print, their influence on the profession will likely increase.

\section{Summary}

Denis made important contributions in theoretical and applied econometrics during his academic career, and he inspired many others to expand the frontiers of econometrics. In our paper, we have reviewed his career, his research publications, and some relationships between his PhD students' research and his own. Much of Denis's research was ahead of its time, as illustrated by the current relevance of his two previously unpublished manuscripts from the 1970s and 1980s. The influence of Denis's research is also visible in many contemporary "hot" topics of research. For instance, dynamic specification and the error correction model are central to the literature on modeling nonstationary economic time series; see Engle and Granger (1991), Johansen (1995), and Ericsson (1998) inter alia. Also, the burgeoning literature on generalized method of moments has its direct antecedent in Denis's analyses of nonlinear IV estimation and hypothesis testing; see Hansen (1982), Newey (1990), and Gallant and Tauchen (1996). We hope that our retrospective will provide new generations of economists with a better understanding of and easier access to Denis's intellectual insights. 


\title{
A Biography and Bibliography for J. Denis Sargan
}

\author{
Born August 23, 1924, in Doncaster, Yorkshire, England \\ 1935-41 Doncaster Grammar School \\ 1941-43 St. John's College, Cambridge [BA in Mathematics, 1944] \\ 1943-46 Junior Scientific Officer, RAF Costal Command \\ 1946-48 St. John's College, Cambridge [BA in Economics, 1948; MA, 1947] \\ 1948-58 Lecturer in Economics, University of Leeds \\ $1958 \quad$ Awarded a Fulbright scholarship \\ 1958-59 Visiting Professor, University of Minnesota \\ 1959-60 Assistant Professor, University of Chicago \\ 1960-63 Reader in Economics, University of Leeds \\ 1963-65 Reader in Statistics, LSE \\ 1965-82 Professor of Econometrics, LSE \\ 1974 Visiting Professor, Yale University \\ 1978-79 Vice President, Econometric Society \\ 1980 President, Econometric Society \\ 1982 Visiting Professor, University of Florida \\ 1982-84 Tooke Professor of Economic Science and Statistics, LSE \\ 1984 Retired from the LSE \\ 1984 Emeritus Professor of Economic Science and Statistics, \\ University of London \\ Died April 13, 1996, in Theydon Bois, Essex, England
}

For ease of reference and citation, the bibliography below is arranged alphabetically by author(s) listed in the publications and then chronologically.

Arellano, M., and J. D. Sargan (1990) "Imhof Approximations to Econometric Estimators", Review of Economic Studies, 57, 4, 627-646.

Bhargava, A., and J. D. Sargan (1983) "Estimating Dynamic Random Effects Models From Panel Data Covering Short Time Periods", Econometrica, 51, 6, 1635-1659.

Espasa, A., and J. D. Sargan (1977) "The Spectral Estimation of Simultaneous Equation Systems with Lagged Endogenous Variables", International Economic Review, 18, 3, 583-605.

Hendry, D. F., A. R. Pagan, and J. D. Sargan (1984) "Dynamic Specification", Chapter 18 in Z. Griliches and M. D. Intriligator (eds.) Handbook of Econometrics, Volume 2, North-Holland, Amsterdam, 1023-1100.

Layard, P. R. G., J. D. Sargan, M. E. Ager, and D. J. Jones (1971) Qualified Manpower and Economic Performance: An Inter-plant Study in the Electrical Engineering Industry, Allen Lane The Penguin Press, London. 
Maasoumi, E. (ed.) (1988) Contributions to Econometrics: John Denis Sargan, Cambridge University Press, Cambridge, England (2 volumes).

Sargan, J. D. (1951) "A New Approach to the General Distribution Problem", Metroeconomica, 3, 3, 108-116.

Sargan, J. D. (1952) "An Illustration of Duopoly", Yorkshire Bulletin of Economic and Social Research, 4, 2, 133-145.

Sargan, J. D. (1953a) "An Approximate Treatment of the Properties of the Correlogram and Periodogram", Journal of the Royal Statistical Society, Series B, 15, 1, $140-152$.

Sargan, J. D. (1953b) "Subjective Probability and the Economist", Yorkshire Bulletin of Economic and Social Research, 5, 1, 53-64.

Sargan, J. D. (1955) "The Period of Production", Econometrica, 23, 2, 151-165.

Sargan, J. D. (1956) “A Note on Mr. Blyth's Article”, Econometrica, 24, 4, 480-481.

Sargan, J. D. (1957a) "The Danger of Over-simplification", Oxford Bulletin of Economics and Statistics (formerly the Bulletin of the Oxford University Institute of Statistics), 19, 2, 171-178.

Sargan, J. D. (1957b) "The Distribution of Wealth", Econometrica, 25, 4, 568-590.

Sargan, J. D. (1958a) "The Estimation of Economic Relationships Using Instrumental Variables", Econometrica, 26, 3, 393-415.

Sargan, J. D. (1958b) "The Instability of the Leontief Dynamic Model", Econometrica, 26, 3, 381-392.

Sargan, J. D. (1958c) "Mrs. Robinson's Warranted Rate of Growth", Yorkshire Bulletin of Economic and Social Research, 10, 1, 35-40.

Sargan, J. D. (1959a) "The Estimation of Relationships with Autocorrelated Residuals by the Use of Instrumental Variables", Journal of the Royal Statistical Society, Series B, 21, 1, 91-105.

Sargan, J. D. (1959b) "Linear Models for the Frequency Distributions of Economic Variables", Econometrica, 27, 2, 315-316 (abstract).

Sargan, J. D. (1961a) "Lags and the Stability of Dynamic Systems: A Reply", Econometrica, 29, 4, 670-673.

Sargan, J. D. (1961b) "The Maximum Likelihood Estimation of Economic Relationships with Autoregressive Residuals", Econometrica, 29, 3, 414-426.

Sargan, J. D. (1964a) "An Approximate Distribution of the Two-stage Least Squares Estimators", Econometrica, 32, 4, 660 (abstract). 
Sargan, J. D. (1964b) "Three-stage Least-squares and Full Maximum Likelihood Estimates", Econometrica, 32, 1-2, 77-81.

Sargan, J. D. (1964c) "Wages and Prices in the United Kingdom: A Study in Econometric Methodology", in P. E. Hart, G. Mills, and J. K. Whitaker (eds.) Econometric Analysis for National Economic Planning, Volume 16 of Colston Papers, Butterworths, London, 25-54 (with discussion).

Sargan, J. D. (1971a) "Asymptotic Expansion for the Distribution Functions of Econometric Estimators", Econometrica, 39, 4, 168 (abstract).

Sargan, J. D. (1971b) "Production Functions", in P. R. G. Layard, J. D. Sargan, M. E. Ager, and D. J. Jones (eds.) Qualified Manpower and Economic Performance: An Inter-plant Study in the Electrical Engineering Industry, Allen Lane The Penguin Press, London, 143-204 (Part 5).

Sargan, J. D. (1971c) "A Study of Wages and Prices in the U.K. 1949-1968", Chapter 4 in H. G. Johnson and A. R. Nobay (eds.) The Current Inflation, Macmillan Press, London, 52-71.

Sargan, J. D. (1974a) "Some Discrete Approximations to Continuous Time Stochastic Models", Journal of the Royal Statistical Society, Series B, 36, 1, 74-90.

Sargan, J. D. (1974b) "The Validity of Nagar's Expansion for the Moments of Econometric Estimators", Econometrica, 42, 1, 169-176.

Sargan, J. D. (1975a) "Asymptotic Theory and Large Models", International Economic Review, 16, 1, 75-91.

Sargan, J. D. (1975b) "Gram-Charlier Approximations Applied to $t$ Ratios of $k$-class Estimators", Econometrica, 43, 2, 327-346.

Sargan, J. D. (1976a) "Econometric Estimators and the Edgeworth Approximation", Econometrica, 44, 3, 421-448 (1977, "Erratum", Econometrica, 45, 1, 272).

Sargan, J. D. (1976b) "Some Discrete Approximations to Continuous Time Stochastic Models", Chapter 3 in A. R. Bergstrom (ed.) Statistical Inference in Continuous Time Economic Models, North-Holland, Amsterdam, 27-79.

Sargan, J. D. (1978) "On the Existence of the Moments of 3SLS Estimators", Econometrica, 46, 6, 1329-1350.

Sargan, J. D. (1980a) "The Consumer Price Equation in the Post War British Economy: An Exercise in Equation Specification Testing", Review of Economic Studies, 47, 1, 113-135.

Sargan, J. D. (1980b) “A Model of Wage-price Inflation", Review of Economic Studies, 47, 1, 97-112. 
Sargan, J. D. (1980c) "Some Approximations to the Distribution of Econometric Criteria Which Are Asymptotically Distributed as Chi-squared", Econometrica, $48,5,1107-1138$.

Sargan, J. D. (1980d) "Some Tests of Dynamic Specification for a Single Equation", Econometrica, 48, 4, 879-897.

Sargan, J. D. (1981) "Identification in Models with Autoregressive Errors", Journal of Econometrics, 16, 1, 160-161 (abstract).

Sargan, J. D. (1982) "On Monte Carlo Estimates of Moments That Are Infinite", in R. L. Basmann and G. F. Rhodes, Jr. (eds.) Advances in Econometrics: A Research Annual, Volume 1, JAI Press, Greenwich, Connecticut, 267-299.

Sargan, J. D. (1983a) "Identification and Lack of Identification", Econometrica, 51, $6,1605-1633$.

Sargan, J. D. (1983b) "Identification in Models with Autoregressive Errors", in S. Karlin, T. Amemiya, and L. A. Goodman (eds.) Studies in Econometrics, Time Series, and Multivariate Statistics: In Honor of Theodore W. Anderson, Academic Press, New York, 169-205.

Sargan, J. D. (1988a) "The Existence of the Moments of Estimated Reduced Form Coefficients", Chapter 6 in E. Maasoumi (ed.) Contributions to Econometrics: John Denis Sargan, Volume 2, Cambridge University Press, Cambridge, England, $133-157$.

Sargan, J. D. (1988b) "The Finite Sample Distribution of FIML Estimators", Chapter 3 in E. Maasoumi (ed.) Contributions to Econometrics: John Denis Sargan, Volume 2, Cambridge University Press, Cambridge, England, 57-75.

Sargan, J. D. (1988c) "The Identification and Estimation of Sets of Simultaneous Stochastic Equations", Chapter 12 in E. Maasoumi (ed.) Contributions to Econometrics: John Denis Sargan, Volume 1, Cambridge University Press, Cambridge, England, 236-249.

Sargan, J. D. (1988d) Lectures on Advanced Econometric Theory, Basil Blackwell, Oxford (edited and with an introduction by Meghnad Desai).

Sargan, J. D. (1988e) "Testing for Misspecification After Estimating Using Instrumental Variables", Chapter 11 in E. Maasoumi (ed.) Contributions to Econometrics: John Denis Sargan, Volume 1, Cambridge University Press, Cambridge, England, 213-235.

Sargan, J. D. (1993a) "Estimation Methods for Simple Rational Expectation Models", Revista Española de Economía (a.k.a. the Spanish Economic Review), 10, 1, 5-18. 
Sargan, J. D. (1993b) "Some Alternatives to the Edgeworth Approximation for Econometric Statistics", Chapter 12 in P. C. B. Phillips (ed.) Models, Methods, and Applications of Econometrics: Essays in Honor of A. R. Bergstrom, Basil Blackwell, Cambridge, Massachusetts, 165-175.

Sargan, J. D. (2001a) "The Choice Between Sets of Regressors", Econometric Reviews, 20 , forthcoming.

Sargan, J. D. (2001b) "Model Building and Data Mining", Econometric Reviews, 20, forthcoming.

Sargan, J. D., and A. Bhargava (1983a) "Maximum Likelihood Estimation of Regression Models with First Order Moving Average Errors When the Root Lies on the Unit Circle", Econometrica, 51, 3, 799-820.

Sargan, J. D., and A. Bhargava (1983b) "Testing Residuals From Least Squares Regression For Being Generated By the Gaussian Random Walk", Econometrica, 51, $1,153-174$.

Sargan, J. D., and E. G. Drettakis (1974) "Missing Data in an Autoregressive Model", International Economic Review, 15, 1, 39-58.

Sargan, J. D., and F. Mehta (1983) "A Generalization of the Durbin Significance Test and Its Application to Dynamic Specification", Econometrica, 51, 5, 1551-1567.

Sargan, J. D., and W. M. Mikhail (1971) "A General Approximation to the Distribution of Instrumental Variables Estimates", Econometrica, 39, 1, 131-169.

Sargan, J. D., and S. E. Satchell (1986) "A Theorem of Validity for Edgeworth Expansions", Econometrica, 54, 1, 189-213.

Sargan, J. D., and Y. K. Tse (1981) "Edgeworth Approximations to the Distribution of Various Test Statistics", Chapter 12 in E. G. Charatsis (ed.) Proceedings of the Econometric Society European Meeting 1979: Selected Econometric Papers in Memory of Stefan Valavanis, North-Holland, Amsterdam, 281-295.

Sargan, J. D., and Y. K. Tse (1988a) "Edgeworth Approximations for 2SLS Estimates of a Dynamic Model", Chapter 8 in E. Maasoumi (ed.) Contributions to Econometrics: John Denis Sargan, Volume 2, Cambridge University Press, Cambridge, England, 172-181.

Sargan, J. D., and Y. K. Tse (1988b) "Some Experience of Numerical Computation of Edgeworth Approximations", Chapter 7 in E. Maasoumi (ed.) Contributions to Econometrics: John Denis Sargan, Volume 2, Cambridge University Press, Cambridge, England, 158-171. 


\section{PhD Theses Supervised by J. Denis Sargan}

In addition to writing research papers on diverse theoretical and applied topics, Denis supervised nearly forty $\mathrm{PhD}$ theses, tabulated and listed below. The range of issues covered by these theses highlights the span of his interests, even while he never published on many of the subjects examined in the theses.

Table 2. A Categorization of PhD Theses Supervised by J. Denis Sargan.

\begin{tabular}{|c|c|c|c|c|c|c|c|c|c|c|}
\hline \multirow[b]{2}{*}{ PhD Thesis } & \multicolumn{3}{|c|}{ Statistical Inference } & \multicolumn{3}{|c|}{ Model Building } & \multicolumn{2}{|c|}{ Empirics } & \multirow{2}{*}{$\begin{array}{l}\text { Ec. } \\
\text { Th. }\end{array}$} & \multirow{2}{*}{ Topic/Application } \\
\hline & IV & $\begin{array}{c}\text { Finite } \\
\text { samples }\end{array}$ & Ident. & $\begin{array}{l}\text { Dyn. } \\
\text { spec. }\end{array}$ & $\begin{array}{l}\text { Num. } \\
\text { comp. }\end{array}$ & $\begin{array}{l}\text { Spec. } \\
\text { search }\end{array}$ & $\begin{array}{l}\text { Wages, } \\
\text { prices }\end{array}$ & $\begin{array}{c}\text { Prod. } \\
\text { fn. }\end{array}$ & & \\
\hline $\begin{array}{l}\text { El Imam }(1957) \\
\text { Hortala-Arau (1966) } \\
\text { Byron (1968) } \\
\text { Handa }(1968) \\
\text { Mikhail (1969) }\end{array}$ & $\bullet$ & $\bullet$ & & & $\bullet$ & $\bullet$ & & & : & $\begin{array}{l}\text { UK consumption function } \\
\text { capital and ec. development } \\
\text { demand systems } \\
\text { Indian import demand } \\
\text { finite sample distributions }\end{array}$ \\
\hline $\begin{array}{l}\text { Rowley }(1969) \\
\text { Trivedi }(1969) \\
\text { Williams }(1969) \\
\text { Charatsis }(1970) \\
\text { Feiner }(1970)\end{array}$ & & $\bullet$ & & : & • & : & & • & : & $\begin{array}{l}\text { UK capital formation } \\
\text { UK inventories } \\
\text { UK consumer durables } \\
\text { Greek manufacturing } \\
\text { UK import demand }\end{array}$ \\
\hline $\begin{array}{l}\text { Hendry }(1970) \\
\text { Vernon }(1970) \\
\text { Wymer }(1970) \\
\text { Drettakis }(1971) \\
\text { Cheong }(1972)\end{array}$ & $\bullet$ & $\bullet$ & $\bullet$ & $\begin{array}{l}\bullet \\
\bullet \\
\bullet\end{array}$ & • & $\bullet$ & $\bullet$ & & • & $\begin{array}{l}\text { systems with AR errors } \\
\text { UK wages and prices } \\
\text { continuous time models } \\
\text { models with missing data } \\
\text { world rubber market }\end{array}$ \\
\hline $\begin{array}{l}\text { Mizon }(1972) \\
\text { Hebden }(1974) \\
\text { Phillips }(1974) \\
\text { Espasa (1975) } \\
\text { Sylwestrowicz (1975) }\end{array}$ & & $\bullet$ & $\bullet$ & : & $\begin{array}{l}\bullet \\
\bullet \\
\bullet\end{array}$ & $\bullet$ & $\bullet$ & $\bullet$ & $\bullet$ & $\begin{array}{l}\text { vintage capital in production } \\
\text { consumer demand } \\
\text { continuous time models } \\
\text { UK wages and prices } \\
\text { random search optimization }\end{array}$ \\
\hline $\begin{array}{l}\text { Fitzpatrick (1976) } \\
\text { Hall (1976) } \\
\text { Maasoumi (1977) } \\
\text { Pesaran (1977) } \\
\text { Ray (1977) }\end{array}$ & $\bullet$ & $\begin{array}{l}\bullet \\
\bullet \\
\bullet\end{array}$ & & • & $\begin{array}{l}\bullet \\
\bullet \\
\bullet\end{array}$ & $\bullet$ & & & • & $\begin{array}{l}\text { international travel market } \\
\text { seemingly unrelated regressions } \\
\text { reduced form estimation } \\
\text { models with measurement errors } \\
\text { UK consumer demand }\end{array}$ \\
\hline $\begin{array}{l}\text { Mehta (1979) } \\
\text { Satchell (1981) } \\
\text { Tse (1981) } \\
\text { Campos Fernandez (1982) } \\
\text { Chong (1982) }\end{array}$ & $\bullet$ & : & $\bullet$ & • & • & & & & & $\begin{array}{l}\text { latent variables models } \\
\text { Edgeworth approximations } \\
\text { Edgeworth approximations } \\
\text { IV estimation with ARMA errors } \\
\text { numerical optimization }\end{array}$ \\
\hline $\begin{array}{l}\text { Ericsson }(1982) \\
\text { Bhargava }(1983) \\
\text { Franzini Bhargava (1983) } \\
\text { Mauleón Torres (1983) } \\
\text { Arellano Gonzalez (1985) }\end{array}$ & $\bullet$ & $\begin{array}{l}\bullet \\
\bullet \\
\bullet \\
\bullet\end{array}$ & & $\begin{array}{l}\bullet \\
\bullet \\
\bullet\end{array}$ & $\bullet$ & : & $\bullet$ & & & $\begin{array}{l}\text { tests of non-nested hypotheses } \\
\text { unit root tests } \\
\text { time-varying coefficient models } \\
\text { asymptotic expansions } \\
\text { dynamic panel data models }\end{array}$ \\
\hline Hunter (1989) & & & $\bullet$ & $\bullet$ & & $\bullet$ & & & $\bullet$ & expectations formation \\
\hline
\end{tabular}

Arellano Gonzalez, Manuel (1985) "Estimation and Testing of Dynamic Econometric Models from Panel Data".

Bhargava, Alok (1983) "The Theory of the Durbin-Watson Statistic with Special Reference to the Specification of Models in Levels as Against in Differences". 
Byron, Raymond Peter (1968) "The Estimation of Systems of Demand Equations Using Prior Information".

Campos Fernandez, Julia (1982) "Instrumental Variables Estimation of Dynamic Economic Systems with Autocorrelated Errors".

Charatsis, Eleftherios G. (1970) "Statistical Methods for Estimation of Production Functions: A Cross-section and Time-series Analysis of the Greek Manufacturing Industry".

Cheong, Kee Cheok (1972) "An Econometric Study of the World Natural and Synthetic Rubber Industry".

Chong, Yock Yoon (1982) "Comparative Methods of Computing Maximum Likelihood Estimates for Non-linear Econometric Systems".

Drettakis, Emmanuel George (1971) "Missing Data in Econometric Estimation".

El Imam, M. M. (1957) "The Consumption Function of the U.K. 1929-1938".

Ericsson, Neil Reinhard (1982) "Testing Non-nested Hypotheses in Systems of Linear Dynamic Economic Relationships".

Espasa, Antoni (1975) "A Wages-earnings-prices Inflation Model for United Kingdom 1950-1970: Its Specification and Estimation by Classical and Spectral Methods".

Feiner, Michael Peter (1970) "An Econometric Study of Disaggregated U.K. Imports, 1958-66".

Fitzpatrick, Michael Desmond (1976) "Varying Parameter Estimation and Trends in the Parameters Which Determine the Modal Choice Associated with Long Distance International Travel".

Franzini Bhargava, Luisa (1983) "Estimating and Testing the Parameters of Time Varying Econometric Models".

Hall, Antony David (1976) "The Relative Efficiency of Estimators of Seemingly Unrelated Regressions".

Handa, Madan Lal (1968) "Econometrics of Import Planning in India (1947-65): A Case Study of Selected Commodities".

Hebden, Julia Jennifer (1974) "A Complete Set of Dynamic Consumer Demand Equations".

Hendry, David Forbes (1970) "The Estimation of Economic Models with Autoregressive Errors".

Hortala-Arau, Juan (1966) "Capital Needs in a Developing Economy: Spain as a Case Study". 
Hunter, John (1989) "Dynamic Modelling of Expectations With Particular Reference to the U.K. Labour Market".

Maasoumi, Esfandiar (1977) "A Study of Improved Methods of Estimating Reduced Form Coefficients Based upon 3SLS Estimators".

Mauleón Torres, Ignacio (1983) "Approximations to the Finite Sample Distribution of Econometric Chi-squared Criteria".

Mehta, Kirtikumar Bharusharker Jatasharker (1979) "Maximum Likelihood Estimation of Economic Relationships Involving Unobservable Indicators".

Mikhail, William Messiha (1969) "A Study of the Finite-sample Properties of Some Econometric Estimators".

Mizon, Grayham Ernest (1972) "The Estimation of Vintage Capital Production Relations".

Pesaran, Bahram (1977) "Estimation of Dynamic Economic Models When Variables Are Subject to Measurement Errors".

Phillips, Peter Charles Bonest (1974) "Problems in the Estimation of Continuous Time Models".

Ray, Ranjan (1977) "Utility Maximisation and Consumer Demand with an Application to the United Kingdom, 1900-1970".

Rowley, John Christopher Robin (1969) "An Econometric Study of Fixed Capital Formation in the British Economy, 1956-1965".

Satchell, Stephen E. (1981) "Edgeworth Approximations in Linear Dynamic Models".

Sylwestrowicz, Jerzy Dowoyna (1975) "Numerical Optimization of Non-linear Functions of Several Variables Using Random Search Techniques".

Trivedi, Pravinchandra Kantilal (1969) "An Econometric Study of Inventory Behaviour in the U.K. Manufacturing Sector, 1956-67".

Tse, Yiu Kuen (1981) "Edgeworth Approximation to the Finite Sample Distribution of Econometric Estimators and Test Statistics".

Vernon, Keith (1970) "An Econometric Study of Wage and Price Inflation in the United Kingdom for the Post-war Period".

Williams, Ross Alan (1969) "An Econometric Study of Post-war Demand for Consumer Durables in the United Kingdom".

Wymer, Clifford Ronald (1970) "Econometric Estimation of Stochastic Differential Equation Systems with Applications to Adjustment Models of Financial Markets". 


\section{Additional References}

Anderson, T. W. (1971) The Statistical Anaylsis of Time Series, John Wiley and Sons, New York.

Campos, J., and N. R. Ericsson (1999) "Constructive Data Mining: Modeling Consumers' Expenditure in Venezuela", Econometrics Journal, 2, 2, 226-240.

Desai, M. J., D. F. Hendry, and G. E. Mizon (1997) "John Denis Sargan", Economic Journal, 107, 443, 1121-1125.

Dicks-Mireaux, L. A., and J. C. R. Dow (1959) "The Determinants of Wage Inflation: United Kingdom, 1946-56", Journal of the Royal Statistical Society, Series A, 122, 2, 145-174 (with discussion).

Engle, R. F., and C. W. J. Granger (eds.) (1991) Long-run Economic Relationships: Readings in Cointegration, Oxford University Press, Oxford.

Ericsson, N. R. (ed.) (1998) Exogeneity, Cointegration, and Economic Policy Analysis, Special Section of the Journal of Business and Economic Statistics, 16, 4, October.

Fisher, F. M. (1966) The Identification Problem in Econometrics, McGraw-Hill, New York.

Gallant, A. R., and G. Tauchen (1996) "Which Moments to Match?", Econometric Theory, 12, 4, 657-681.

Hall, P. (1992) The Bootstrap and Edgeworth Expansion, Springer-Verlag, New York.

Hansen, L. P. (1982) "Large Sample Properties of Generalized Method of Moments Estimators", Econometrica, 50, 4, 1029-1054.

Hausman, J. A. (1975) "An Instrumental Variable Approach to Full Information Estimators for Linear and Certain Nonlinear Econometric Models", Econometrica, $43,4,727-738$.

Hendry, D. F. (1976) "The Structure of Simultaneous Equations Estimators", Journal of Econometrics, 4, 1, 51-88.

Hendry, D. F. (1984) "Monte Carlo Experimentation in Econometrics", Chapter 16 in Z. Griliches and M. D. Intriligator (eds.) Handbook of Econometrics, Volume 2, North-Holland, Amsterdam, 937-976.

Hendry, D. F. (2000) Econometrics: Alchemy or Science?, Oxford University Press, Oxford, New Edition.

Hendry, D. F., and R. W. Harrison (1974) "Monte Carlo Methodology and the Small Sample Behaviour of Ordinary and Two-stage Least Squares", Journal of Econometrics, 2, 2, 151-174. 
Hendry, D. F., and G. E. Mizon (2000) "The Influence of A.W. Phillips on Econometrics", Chapter 38 in R. Leeson (ed.) A.W.H. Phillips: Collected Works in Contemporary Perspective, Cambridge University Press, Cambridge, England, 353-364.

Hendry, D. F., and K. F. Wallis (eds.) (1984) Econometrics and Quantitative Economics, Basil Blackwell, Oxford.

Johansen, S. (1995) Likelihood-based Inference in Cointegrated Vector Autoregressive Models, Oxford University Press, Oxford.

Kmenta, J. (1967) "On Estimation of the CES Production Function", International Economic Review, 8, 2, 180-189.

Liu, T.-C. (1960) "Underidentification, Structural Estimation, and Forecasting", Econometrica, 28, 4, 855-865.

Maasoumi, E. (1978) "A Modified Stein-like Estimator for the Reduced Form Coefficients of Simultaneous Equations", Econometrica, 46, 3, 695-703.

Maasoumi, E. (1980) "A Ridge-like Method for Simultaneous Estimation of Simultaneous Equations", Journal of Econometrics, 12, 2, 161-176.

Maasoumi, E. (1986) "Reduced Form Estimation and Prediction from Uncertain Structural Models: A Generic Approach", Journal of Econometrics, 31, 1, 3-29.

Maasoumi, E. (1988a) "Contributions of Denis Sargan to the Theory of Finite Sample Distributions and Dynamic Econometric Models", Chapter 1 in E. Maasoumi (ed.) Contributions to Econometrics: John Denis Sargan, Volume 2, Cambridge University Press, Cambridge, England, 1-17.

Maasoumi, E. (1988b) "Denis Sargan and His Seminal Contributions to Economic and Econometric Theory", Chapter 1 in E. Maasoumi (ed.) Contributions to Econometrics: John Denis Sargan, Volume 1, Cambridge University Press, Cambridge, England, 1-18.

Mizon, G. E. (1977) "Inferential Procedures in Nonlinear Models: An Application in a UK Industrial Cross Section Study of Factor Substitution and Returns to Scale", Econometrica, 45, 5, 1221-1242.

Mizon, G. E. (1995a) "Progressive Modeling of Macroeconomic Time Series: The LSE Methodology", Chapter 4 in K. D. Hoover (ed.) Macroeconometrics: Developments, Tensions, and Prospects, Kluwer Academic Publishers, Boston, Massachusetts, 107-170 (with discussion).

Mizon, G. E. (1995b) "A Simple Message for Autocorrelation Correctors: Don't", Journal of Econometrics, 69, 1, 267-288.

Mizon, G. E. (1996) "Denis Sargan: Obituary”, The Guardian, Monday 13 May, 10. 
Newey, W. K. (1990) "Efficient Instrumental Variables Estimation of Nonlinear Models", Econometrica, 58, 4, 809-837.

Phillips, P. C. B. (1983) "Exact Small Sample Theory in the Simultaneous Equations Model", Chapter 8 in Z. Griliches and M. D. Intriligator (eds.) Handbook of Econometrics, Volume 1, North-Holland, Amsterdam, 449-516.

Phillips, P. C. B. (1985) "ET Interviews: Professor J. D. Sargan", Econometric Theory, 1, 1, 119-139.

Rothenberg, T. J. (1971) "Identification in Parametric Models", Econometrica, 39, 3, $577-591$.

Sargan, J. D. (1987) "The Method of Iterative Maximization", in M. L. King and D. E. A. Giles (eds.) Specification Analysis in the Linear Model (In Honour of Donald Cochrane), Routledge and Kegan Paul, London, 353-354 (Appendix 3).

Schwarz, G. (1978) "Estimating the Dimension of a Model", Annals of Statistics, 6, $2,461-464$. 